\title{
Indeksy do ksiąg ziemskich, grodzkich i podkomorskich z wieków XVIII i XIX w Archiwum Państwowym w Lublinie
}

abstrakt: Jednym z najcenniejszych zbiorów znajdujących się w Archiwum Państwowym w Lublinie jest 35/2564 Zbiór indeksów do ksiąg ziemskich, grodzkich i podkomorskich z zasobu Archiwum Akt Dawnych w Lublinie. Indeksy powstały na przestrzeni od ostatniej ćwierci XVIII w. do połowy lat 8o. XIX w. Spisano je we Lwowie, w tzw. archiwum bernardyńskim, oraz w Archiwum Akt Dawnych w Lublinie, w celu sprawnego wykonywania kwerend w księgach sądowych, powstałych w szlacheckich sądach grabowieckich, horodelskich, dawnego województwa lubelskiego i ziemi chełmskiej. Indeksy zawierają imiona i nazwiska osób (stron) działających w sprawie, jej rodzaj oraz nazwę miejscowości, której sprawa dotyczy. Do 1887 r. indeksy przechowywano w Lublinie. Następnie wywieziono je do Wilna, skąd powróciły W 1919 r.

sŁowa KLUczowe: indeksy, archiwum bernardyńskie we Lwowie, Archiwum Akt Dawnych w Lublinie, Jan Roman, Hieronim Duchnowski, Józef Detmerski.

\section{Historia powstania i losy indeksów w XVIII-XX w.}

W Archiwum Państwowym w Lublinie przechowywany jest pod numerem 35/2564 Zbiór indeksów do ksiąg ziemskich, grodzkich i podkomorskich z zasobu Archiwum Akt Dawnych w Lublinie, opracowany w 2017 r. przez piszącego te 
słowa. Składają się na niego dwie grupy ksiąg. Pierwsza to indeksy z archiwum tzw. bernardyńskiego we Lwowie ${ }^{1}$, powstałe u schyłku XVIII w. do ksiąg ziemskich i grodzkich grabowieckich i horodelskich. Druga to indeksy Jana z Dukli Romana, Hieronima Duchnowskiego i Józefa Detmerskiego ${ }^{2}$, ułożone w ciągu XIX w. w Archiwum Akt Dawnych w Lublinie, odnoszące się do ksiąg: a) ziemskich: chełmskich, krasnostawskich, lubelskich, parczewskich, urzędowskich; b) grodzkich: chełmskich, krasnostawskich, lubelskich, szczebrzeskich; c) podkomorskich: chełmskich, lubelskich, łukowskich.

Geneza indeksów lwowskich i lubelskich związana była ze zmianami, jakie zaszły w znaczeniu ksiąg staropolskich sądów szlacheckich: ziemskiego, grodzkiego i podkomorskiego, spowodowanymi rozbiorami I Rzeczypospolitej i wprowadzeniem przez Austrię i Rosję nowych form administracji na zajętych terenach. Równorzędną rolę w ich początkach odegrała potrzeba praktycznego, często urzędowego wykorzystania informacji zawartych w księgach, ale także wynikająca z traktowania ich jako źródła wiedzy o przeszłości (np. niektóre zestawienia w sumariuszach J. Romana). Istnienie staropolskich akt spowodowało więc powstanie indeksów, stąd ich ścisły związek, który sprowadził się tak do zawartych w nich treści, jak też do wspólnych losów.

Po I rozbiorze Polski w 1772 r. władze Austrii utworzyły z zajętych ziem Królestwo Galicji i Lodomerii ${ }^{3}$, w którego granicach znalazły się także Grabowiec i Horodło. Związane z tym zmiany polityczne spowodowały, że urządzenia ustrojowe z czasów I Rzeczypospolitej stopniowo zastąpiono nowymi formami administracji, wprowadzonymi przez cesarzową Marię Teresę na przełomie lat 70. i 80. XVIII w. Sądownictwo ziemskie i grodzkie na terenie Galicji po 1772 r. utrzymało się przez kilka lat $\mathrm{w}$ niezmienionej formie ${ }^{4}$. Reformę zapoczątkował patent cesarzowej z 4 III 1780 r., na mocy którego utworzono księgi tabularne i nakazano przenosić do nich z ksiąg ziemskich i grodzkich zapisy o hipotece na posiadanych dobrach $^{5}$. W 1783 r. sądy ziemskie i grodzkie zostały zlikwidowane. Od 1 I 1784 r.

${ }^{1}$ Dla ułatwienia nazywane będą także „indeksami lwowskimi”.

2 Dla ułatwienia nazywane będą także „indeksami lubelskimi”.

${ }^{3}$ Rozkazy y ustawy powszechne Krolestwom Galicyi y Lodomeryi od dnia 11. września 1772 obięcia possessyi ogłoszone, Lwów (b.d.), nr I; S. Sochaniewicz, Archiwum Krajowe Akt Grodzkich i Ziemskich we Lwowie, Lwów 1912, s. 32.

${ }^{4}$ Rozkazy y ustawy, nr IV.

${ }^{5}$ S. Sochaniewicz, dz. cyt., s. 33 . 
rozpoczęły działalność tzw. sądy szlacheckie (Forum Nobilium). Pierwszy z nich powstał we Lwowie, a kolejne w 1787 r. w Tarnowie i Stanisławowie ${ }^{6}$.

Reforma sądownictwa stała się kluczowa dla losów ksiąg ziemskich i grodzkich powiatów włączonych po I rozbiorze do Austrii, bowiem przestały działać urzędy, które były ich wytwórcami. W związku z tym, w grudniu 1783 r. władze austriackie zdecydowały o przewiezieniu wszystkich ksiąg sądów szlacheckich (w tym grabowieckich i horodelskich) do Lwowa ${ }^{7}$. W 1784 r. złożono je w pomieszczeniach klasztoru oo. bernardynów, w ich dawnej bibliotece. Pieczę nad aktami objął 9 XII 1784 r. Antoni Poletyło, jako regens actorum antiquorum. Tym samym powstało tzw. „archiwum bernardyńskie” o oficjalnej nazwie Cesareo-regium antiquorum actorum terrestrium et castrensium Galiciensium tum corroborationis documentorum officium, którego zasób nazywano „aktami bernardyńskimi”" .

Likwidacja sądów ziemskich i grodzkich z okresu I Rzeczypospolitej nie oznaczała dla ksiąg sądowych całkowitej utraty ich znaczenia. Duża część zapisów, które się w nich znajdowały, nadal służyła jako dowód zdziałanych czynności prawnych i wykorzystywana była przez szlachtę w życiu codziennym. Kwerendy w księgach, potrzebne przy poświadczaniu dokumentów ${ }^{9}$, ale także przy udowodnieniu szlachectwa, niezbędnym w staraniach o tytuł hrabiego i barona ${ }^{10}$, nie były łatwe do wykonania w nieuporządkowanej i nierozpoznanej masie akt zwiezionych z różnych grodów. Z powyższych przyczyn w 1785 r. stany galicyjskie złożyły na dworze Marii Teresy prośbę i projekt uporządkowania akt bernardyńskich, a w $1787 \mathrm{r}$. uzyskały zgodę cesarzowej na podjęcie działań. Odpowiednią instrukcję w tej sprawie otrzymał A. Poletyło ${ }^{11}$. Zakładano w niej, że prace nad porządkowaniem ksiąg ziemskich i grodzkich będą się toczyły trójtorowo. Po pierwsze należało ponumerować księgi i strony w każdej z nich, po drugie sporządzić indeksy do zapisów,

${ }^{6}$ Tamże.

${ }^{7}$ Akta grodzkie i ziemskie z czasów Rzeczypospolitej Polskiej z Archiwum tak zwanego bernardyńskiego we Lwowie (dalej AGZ). T. I, wyd. L. Tatomir, Lwów 1868, s. X-XI; S. Sochaniewicz, dz. cyt., s. 33 .

${ }^{8}$ A. Schneider, Encyklopedya krajoznawstwa Galicyi pod względem historycznym, statystycznym, topograficznym, orograficznym, geognostycznym, etnograficznym, handlowym, przemystowym, sfragistycznym, etc. T. 1, Lwów 1871, s. 146.

9 P. Dąbkowski, Palestra i księgi sądowe ziemskie i grodzkie w dawnej Polsce, Lwów 1926, s. 87; W. Dolinowski, Gromadzenie zbiorów archiwum bernardyńskiego we Lwowie w latach 1784-1933, „Archeion” T. 115, 2014, s. 259-260.

${ }^{10}$ S. Sochaniewicz, dz. cyt., s. 33.

${ }^{11}$ AGZ, s. XI; A. Schneider, dz. cyt., s. 147; S. Sochaniewicz, dz. cyt., s. 33-34. 
które się w nich znajdowały, po trzecie przepisać nieczytelne kopie ${ }^{12}$. Prace nad uporządkowaniem archiwum bernardyńskiego rozpoczęly się w 1787 r., a skończyły w 1800 r. $^{13}$ Do paginowania i indeksowania ksiąg zatrudniono 150 pisarzy, którzy pracowali pod przewodnictwem Feliksa Kownackiego ${ }^{14}$. Najważniejszym efektem działań podjętych $\mathrm{w}$ archiwum lwowskim było powstanie indeksów do ksiąg ziemskich i grodzkich dawnych województw ruskiego i bełskiego.

Do klasztoru bernardynów we Lwowie trafiły księgi sądowe grabowieckie i horodelskie. Przewieziono je zapewne wraz z innymi aktami w 1784 r., ale jeszcze pod koniec XVIII w. zasób ksiąg obydwu grodów uzupełniano. Z 1797 r. zachował się list proboszcza parafii w Stojanowie, Grzymały, do regenta Poletyły, w którym czytamy:

Będąc w Włodzimirzu w konwencie OO Dominikanów, w których archiwum tamecznego województwa jest złożone, przypadkiem przyszedłszy do teyże kancelarii postrzegłem protokół grodu horodelskiego, który za usilnym staraniem się pozyskałem go odebrać (...), przeto uprosiłem Wielmożnego Wolanskiego (...), którego znając naypewnieysze ręce jako obywatela galicyjskiego, aby tenże, jako rządcy całego archiwum galicyjskiego W[aszmość] Panu Dobrodziejowi [protokół] odda $1^{15}$.

Wymieniona przez księdza Grzymałę księga to protokół zapisów grodzkich horodelskich z lat 1761-1771, zindeksowany we Lwowie dopiero w 1797 r. Przypadek ten, być może nie jedyny, zważywszy na fakt regestowania kilku innych ksiąg grabowieckich i horodelskich u schyłku XVIII w., skłania do wniosku, że albo z kancelarii grodzkich nie przewieziono do Lwowa wszystkich akt, albo pojedyncze księgi znajdowały się poza nimi jeszcze przed $1784 \mathrm{r}$.

Prace nad uporządkowaniem ksiąg grabowieckich i horodelskich trwały od 1787 r. do 1799 r., z dłuższą przerwą od 1792 do 1797 r., przy czym zasadnicza ich część, czyli indeksowanie, przypadła na lata 1790-1792. W tworzeniu indeksów

12 AGZ, s. XI; A. Schneider, dz. cyt., s. 147.

${ }^{13}$ S. Sochaniewicz, dz. cyt., s. 34. L. Tatomir (AGZ, s. XI), a za nim A. Schneider (dz. cyt., s. 147) jako datę zakończenia prac porządkowych w archiwum podają rok 1790. Zważywszy jednak, że indeksy do ksiąg grabowieckich i horodelskich powstawały w latach 1791-1792 oraz 1797-, bardziej prawdopodobny jest rok 1800 .

${ }^{14}$ P. Dąbkowski, dz. cyt., s. 87.

15 Archiwum Państwowe w Lublinie (dalej APL), Księgi grodzkie horodelskie (dalej Kgh), Zapisy, sygn. 32, s. 269. Księga z lat 1761-1771. 
uczestniczyło 106 osób, jako układających ich treść. Tyle nazwisk odnotowano na stronach tytułowych poszczególnych woluminów ${ }^{16}$. Do tej grupy należy doliczyć pisarzy, którzy przy regestowaniu kolacjonowali treść zapisów, jednak ich dokładnej liczby nie da się ustalić. Niewykluczone, że przy księgach grabowieckich i horodelskich zatrudniony był cały personel archiwum. Podczas indeksowania ksiąg nie było specjalizacji zajęć. Każdy z pisarzy zarówno kolacjonował treść wpisu w księdze, jak też spisywał indeks.

Zgodnie z założeniami z 1787 r. porządkowanie ksiąg sądowych grabowieckich i horodelskich rozpoczęto od paginowania, nieodzownego do ułożenia indeksów. Z zapisów o treści „Paginavit per Ignatium Kuczynski die 23 Augusti 1787”" „Die 23 Augusti 1787 paginavit Vitalis Drogon”" ${ }^{18}$; „Paginavit Andreas Podhorecki die 28 Septembris $1787^{\prime 19}$ wynika, że strony w woluminach numerowano co najmniej w ciągu dwóch miesięcy: w sierpniu i wrześniu 1787 r., a do czynności tej zaangażowani byli jednocześnie różni pisarze, którzy w zależności od liczby stron mogli w ciągu jednego dnia wykonać paginację od jednej do kilku ksiąg. Daty zakończenia tych prac nie znamy.

Wzmianki o kolacjonowaniu indeksów z księgami, zachowane w aktach sądowych grabowieckich i horodelskich ${ }^{20}$, wskazują, że w $1790 \mathrm{r}$. trwało już ich indeksowanie. Pierwszą grupą akt, którą regestowano, były księgi grodzkie horodelskie. Indeksy do nich zaczęto spisywać przed $30 \mathrm{~V} 1790 \mathrm{r}^{21}$, a zakończono najpóźniej w lipcu 1791 r. Pracowało przy tym 44 pisarzy. Na lata 1791-1792 przypada indeksowanie ksiąg ziemskich grabowieckich i horodelskich oraz grodzkich grabowieckich. Indeksy do tych ostatnich zaczęły powstawać już w styczniu $1791 \mathrm{r}^{22}$, do ziemskich grabowieckich około maja tego roku ${ }^{23}$. W przypadku ksiąg ziemskich horodelskich wiemy, że indeksy do nich spisywano w maju $1792 \mathrm{r}^{24}$, ale inne daty trudno ustalić, ponieważ zachowały się tylko dwie księgi horodelskiego

${ }^{16}$ Zakładamy, że osoby o takich samych nazwiskach i różnych imionach nie są tożsame.

${ }^{17}$ Kgh, Wyroki, sygn. 63, k. 1 nlb. r.

18 Tamże, Relacje, sygn. 41, k. 1 nlb. v.

${ }^{19}$ Kgh, Zapisy, sygn. 31, s. 332.

${ }^{20}$ Wpisy te znajdują się najczęściej na wewnętrznych stronach okładek ksiąg grodzkich i ziemskich lub na tzw. ante i post folium, dlatego zrezygnowano z każdorazowego opisywania miejsca wpisu, z wyjątkiem takich, które zanotowano na numerowanych stronicach.

${ }^{21}$ Kgh, Zapisy, sygn. 7.

22 APL, Księgi grodzkie grabowieckie (dalej Kgg), Wyroki, sygn. 171.

${ }^{23}$ APL, Księgi ziemskie grabowieckie (dalej Kzg), Wyroki, sygn. 21.

${ }^{24}$ APL, Zbiór indeksów do ksiąg ziemskich, grodzkich i podkomorskich z zasobu Archiwum Akt Dawnych w Lublinie (dalej Zbiór indeksów), sygn. 49, s. 268. 
sądu ziemskiego. Prace związane z regestowaniem zapisów i kolacjonowaniem treści zakończono w grudniu 1792 r. Pojedyncze indeksy do akt obydwu grodów powstawały jeszcze w latach $1795,1797,1798,1799$. W sumie w archiwum bernardyńskim we Lwowie w latach 1790-1799 spisano 361 tomów indeksów: 41 do ksiąg ziemskich grabowieckich; 13 do ziemskich horodelskich; 245 do ksiąg grodzkich grabowieckich; 61 do grodzkich horodelskich oraz 1 do księgi grodzkiej krasnostawskiej z serii Relacje z lat 1654, 1655, 1688, która w nieznanych okolicznościach znalazła się wśród akt wywiezionych w 1784 r. do Lwowa ${ }^{25}$.

Wspomniane wyżej zapiski o kolacjonowaniu ksiąg sądowych grabowieckich i horodelskich są źródłem do poznania zarówno metod pracy zastosowanych przy indeksowaniu, jak też wymiaru czasu, jaki potrzebny był do ułożenia samego indeksu. Wpisy te występują w dwóch odmianach. Na pierwszą grupę składa się od kilku do nawet kilkudziesięciu notatek zawierających: datę kolacjonowania, informację o sprawdzonych stronach indukty i/bądź protokołu („,a pagina... ad paginam...”), stwierdzenie faktu wykonania czynności („collationavi”) oraz nazwisko pracownika, który dokonał sprawdzenia, zanotowane albo obok każdej daty osobno, albo po kilku, kilkunastu lub po wszystkich. Druga grupa zapisów składa się z jednej daty oraz informacji o kolacjonowaniu księgi przez konkretną osobę lub osoby („1791 die 11 Novembris a pagina prima ad finem libri videlicet ad paginam 960 cum Domino Harasimowicz indicante collationavi Bilinski" ${ }^{26}$. Wymienione rodzaje zapisek uzupełniają inne, informujące wprost o początku lub zakończeniu indeksowania oraz czasie trwania prac, znajdujące się zarówno w księgach ziemskich i grodzkich, jak też w samych indeksach.

Indeksy do ksiąg sądowych grabowieckich i horodelskich sporządzano dwiema metodami. Pierwsza z nich polegała na zindeksowaniu wszystkich zapisów znajdujących się w danej księdze, po czym następowało kolacjonowanie regestów z wpisami. Etap prac związany ze sprawdzaniem poprawności wykonania indeksów mógł się odbyć jednorazowo („Die 18 Novembris 1791 cum generoso Andrea Zielonka collationavi et revidi indicem, Franciscus Kodrębski”27; „Pagina 1-ma ad finem ide est paginam 1278 die 28 Augusti 1791 cum generoso Żędzian collationavi, Czuryło"28) lub etapami ${ }^{29}$. Drugi sposób polegał na zindeksowaniu

25 Tamże, sygn. 361. Por. AGZ, s. X.

${ }^{26} \mathrm{Kgg}$, Zapisy, sygn. 37, k. nlb. r. po s. 960.

27 Tamże, Relacje, sygn. 148.

28 Tamże, Zapisy, sygn. 40.

29 Może za tym przemawiać zapis: „Deo adiuvante, cum magnifico Mathaeo Sobolewski venatore Podlachiae die 15 Maii finivi collationem, Theodorus Turzanski” - tamże, sygn. 66, s. 802. 
danego fragmentu księgi, po czym jego kolacjonowaniu. Przykładem dobrze to obrazującym są prace nad regestami wpisów znajdujących się w księdze grodzkiej grabowieckiej o sygn. $31 \mathrm{z}$ serii Inscriptiones (indukta z lat 1647-1656, ss. 2622) ${ }^{30}$ i odpowiadającymi jej protokołom o sygn. 58, 59, 60 z lat 1647-1662. Najpóźniej 7 VII 1791 r. zakończyło się indeksowanie pierwszego z wymienionych protokołów, obejmującego lata 1647-1650, oraz zapisów w indukcie (s. 1-1146). Fakt sprawdzenia poprawności wykonania indeksów odnotowano w protokole ${ }^{31} \mathrm{i}$ krótkiej notatce "Collatio die 7 Julii, w indukcie” ${ }^{\text {. }}$. Kolejny etap zakończył się 30 VIII 1791 r., gdy zindeksowano zapisy z protokołu o sygn. 59 (z lat 1651-1655, ss. 617), $\mathrm{z}$ fragmentu protokołu o sygn. 60 ( $\mathrm{z}$ lat $1655-1656$, s. $1-35)^{33}$ oraz odpowiadające

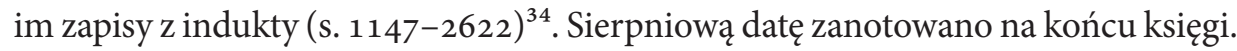

Wybór metody pracy mógł być podyktowany różnymi względami. Wprawdzie nie można w tym przypadku wykluczyć osobistych preferencji pisarza, ale najbardziej prawdopodobne, choć trudne do udokumentowania w źródłach, wydają się czynniki logistyczne, związane z zaangażowaniem poszczególnych pracowników archiwum w różne prace, być może konieczne w danej chwili do wykonania. Wskazywałoby na to wielokrotne kolacjonowanie zapisów jednej księgi, rozciągnięte w czasie do kilku miesięcy i zapewne w wielu przypadkach trwające dłużej niż samo regestowanie. $Z$ notatki znajdującej się w księdze grodzkiej grabowieckiej wynika, że 14 III 1791 r. została ona zabrana do indeksowania, pierwsze sprawdzenie nastąpiło 14 VI 1791 r., a ostatnie $13 \mathrm{X}^{35}$. Prace nad sporządzeniem indeksu do ponad 500-stronicowej księgi trwały więc trzy miesiące, a kolacjonowanie cztery. Z innych zapisów dowiadujemy się, że protokół księgi zawierający 369 stron jeden z pisarzy, Feliks Kownacki, samodzielnie kolacjonował od 7 do 21 VIII 1792 r. $^{36}$ Przy jednorazowym sczytywaniu, w ciągu dnia, dwóch pracowników archiwum mogło sprawdzić $\mathrm{z}$ indeksem zapisy nawet $\mathrm{z} 1500$ stron ksiąg sądowych ${ }^{37}$.

Indeksy powstałe w XIX w. w Archiwum Akt Dawnych w Lublinie to 59 ksiąg sporządzonych do akt sądów szlacheckich grodów dawnego województwa

\footnotetext{
30 Tamże, sygn. $31-\mathrm{z}$ lat 1647-1656.

31 Tamże, sygn. 58, s. 399: „1791 die 7 Julii a pagina prima ad finem protocolli scilicet ad paginam 398, ex inductae autem ad paginam 1146, collationavi Bilinski cum indicante Winarski”.

${ }^{32}$ Tamże, sygn. 31, s. 1147.

${ }^{33} \mathrm{~W}$ obydwu przypadkach fakt kolacjonowania odnotowano w protokole.

${ }^{34}$ Tą metodą także np. Kgg, Relacje, sygn. 147; sygn. 157 i szereg innych.

35 Tamże, sygn. 147: „Die 14 Martii ad indicandum assumptum liber ide”.

${ }^{36}$ Zbiór indeksów, sygn. 21, s. 428.

${ }^{37}$ Kgg, Zapisy, sygn. 58, s. 399.
} 
lubelskiego i ziemi chełmskiej. Ułożyli je pracownicy archiwum: Jan z Dukli Roman $^{38}$, Hieronim Duchnowski ${ }^{39}$ i Józef Detmerski ${ }^{40}$.

Geneza powstania skorowidzów jest podobna do początków indeksów z archiwum bernardyńskiego we Lwowie. Po III rozbiorze Polski województwo lubelskie (powiat lubelski i urzędowski) oraz znaczna część ziemi chełmskiej (z Chełmem i Krasnymstawem) znalazły się pod zaborem austriackim ${ }^{41}$. W $1796 \mathrm{r}$. zamknięte zostały kancelarie grodzkie i ziemskie, a pozostałe po ich działalności akta władze zaborcze uznały za „milczące”. W ich miejsce otwarto nowe księgi ziemskie, które prowadzić mieli dotychczasowi regenci kancelarii grodzkich. Sądownictwo na terenie tzw. Galicji Zachodniej oddano utworzonemu w Lublinie Forum Nobilium, któremu podlegały kancelarie ziemskie znajdujące się m.in. w Lublinie, Chełmie, Krasnymstawie, Parczewie oraz Łukowie ${ }^{42}$. Staropolskie akta sądowe pozostawiono w miejscach dotychczasowego przechowywania (kancelarie sądowe, zamki, budynki klasztorne) ${ }^{43}$. W 1810 r., w okresie Księstwa Warszawskiego, księgi oddano pod nadzór sądów pokoju ${ }^{44}$. Taki stan rzeczy trwał do 1825 r., gdy namiestnik Królestwa Polskiego Józef Zajączek wydał nakaz koncentracji akt sądowych w miastach wojewódzkich i ich uporządkowania ${ }^{45}$. Decyzja ta legła u podstaw organizacji w Lublinie Archiwum Akt Dawnych. Powstało ono na mocy zarządzenia Komisji Sprawiedliwości wydanego w 1827 r. Pierwszym opiekunem lubelskiego archiwum został Piotr Zagrobski ${ }^{46}$.

${ }^{38}$ Z aktu małżeństwa Jana z Dukli Romana z Katarzyną z Sobolewskich z 1824 r. wynika, że lubelski archiwista urodził się we Lwowie ok. 1770 r. Patrz: Archiwum Państwowe w Warszawie, Akta stanu cywilnego (dalej Asc) parafii Sobików, sygn. 34, nr 3. Był kapitanem wojsk polskich i w 1824 r. właścicielem Czaplina Wielkiego, położonego dzisiaj w gminie Góra Kalwaria. Zmarł 19 maja 1841 r. (APL, Asc par. pw. św. Jana w Lublinie, sygn. 21, nr 189).

${ }^{39}$ Hieronim Duchnowski, archiwista Archiwum Głównego w Warszawie, w latach 1842-1845? archiwista w Archiwum Akt Dawnych w Lublinie. Patrz: J. Mioduszewski, Hieronim Duchnowski, [w:] Polski Słownik Biograficzny. T. 5, Kraków 1939-1946, s. 443.

${ }^{40}$ Józef Detmerski (1815-1892), archiwista w Archiwum Akt Dawnych w Lublinie w latach 1862-1885. Patrz biogram: P. Dymmel, Józef Detmerski, [w:] Słownik Biograficzny Archiwistów Polskich. T. 3, 1835-2015, Warszawa 2017, s. 61-62.

${ }^{41}$ A. Korobowicz, W. Witkowski, Historia ustroju i prawa polskiego (1772-1918), wyd. 5, Warszawa 2012, s. 15.

${ }^{42}$ T. Mencel, Archiwum Akt Dawnych w Lublinie (1827-1887), „Rocznik Lubelski” T. 1, 1958, s. 7.

43 Tamże, s. 8.

44 Tamże, s. 9.

45 Tamże, s. 15.

46 Tamże, s. 16. 
W latach 1827-1829 do Lublina zwieziono staropolskie księgi ziemskie, grodzkie i podkomorskie, znajdujące się dotąd przy sądach pokoju. Rozpoczął się proces ich porządkowania, zakończony w 1832 r. sporządzeniem wykazu ksiąg sądowych znajdujących się w lubelskim archiwum, przygotowanym przez P. Zagrobskiego (tzw. konsygnacja Zagrobskiego) ${ }^{47}$.

Księgi sądów szlacheckich dawnego województwa lubelskiego i ziemi chełmskiej, szczególnie te z XVIII w., choć zarchiwizowane, nie straciły na znaczeniu. Nadal wykorzystywane były jako dowód zdziałanych czynności prawnych, przede wszystkim w sprawach majątkowych prowadzonych przez szlachtę. Zainteresowanie nimi wzmogło się w 1836 r., po utworzeniu Heroldii Królestwa Polskiego, przed którą należało udowodnić swoje szlachectwo. Księgi sądowe miały w tej sprawie pierwszorzędne znaczenie, ponieważ pochodzące z nich wypisy były podstawą uznania klejnotu ${ }^{48}$. Zapotrzebowanie na kwerendy stało się więc czynnikiem, który zadecydował o konieczności indeksowania ksiąg. Działania w tym kierunku podjął prawdopodobnie jeszcze w 1838 r., tuż po zatrudnieniu w lubelskim archiwum, Jan Roman ${ }^{49}$. Pierwszy etap tych prac powiązany był z porządkowaniem luzów ksiąg sądowych (tzw. plików). Zaowocował on powstaniem sumariusza znalezionych dokumentów, zapisów majątkowych, inwentarzy i protokołów spraw sądowych, dotyczących zakonów, klasztorów, kościołów parafialnych oraz miast ${ }^{50}$. Sumariusz ten Roman wykonał samodzielnie, ale jednocześnie zgłosił Prezesowi Trybunału Cywilnego w Lublinie (dalej jako TC) zapotrzebowanie na nowych pracowników, którzy pomagaliby mu przy numerowaniu kart w księgach i ich dalszym indeksowaniu ${ }^{51}$. Prośby zgłaszane kilkakrotnie w tej sprawie ${ }^{52}$ poskutkowały w kwietniu

${ }^{47}$ J. Riabinin, Archiwum Państwowe w Lublinie, Warszawa 1926, s. 13; T. Mencel, dz. cyt., s. $20-26$.

48 T. Mencel, dz. cyt., s. 19.

49 Tamże, s. 26, 27. Jan z Dukli Roman pracował w Archiwum Akt Dawnych w Lublinie aż do swojej śmierci w $1841 \mathrm{r}$.

${ }^{50}$ APL, Trybunał Cywilny I Instancji w Lublinie (dalej Trybunał), sygn. 16, k. 3-5: „Spis dokumentów dotyczących instytutów publicznych, przy porządkowaniu archiwum akt nowych Guberni Lubelskiey wynalezionych przez archiwistę tychże akt Jana z Dukli Romana sporządzony”. Sumariusz liczy 117 pozycji.

${ }^{51}$ Tamże, k. 2, raport J. Romana do Prezesa Trybunału Cywilnego Guberni Lubelskiej z dn. 30 VI/12 VII 1839 r.: „(...) a wtedy mogą bydź foliowane i zebrane na summaryusze, do tego potrzebaby naymniey dziesięciu osób, choćby nie łacinników, a ci pod moim dozorem uskuteczniliby".

52 Tamże, sygn. 14, k. 1, 2. 
1840 r. zatrudnieniem m.in. Jakuba Szumskiego. Powierzono mu stanowisko dietariusza, związane ze spisywaniem sumariuszy ${ }^{53}$.

Od kwietnia 1840 r., przy większej obsadzie personalnej archiwum, prace nad indeksowaniem prowadzone były systematycznie. Do sierpnia $1840 \mathrm{r}$. powstały seryarze do ksiąg grodzkich lubelskich z lat 1742-1746, J. Szumski zaczął indeksować także księgi z lat 60. XVIII w. ${ }^{54}$ Śmierć J. Romana w maju $1841 \mathrm{r}^{55}$ wstrzymała na pewien czas indeksowanie. Podjęto je ponownie w 1842 r., gdy archiwistą w lubelskim archiwum został Hieronim Duchnowski.

Efektem działalności J. Romana i jego współpracowników były 22 sumariusze do ksiąg lubelskich, chełmskich i krasnostawskich z XVIII w. ${ }^{56}$ Składały się na nie indeksy do wybranych serii, zestawienia urzędników, wykazy przywilejów i dokumentów oblatowanych w aktach grodzkich, spisy szlachty, genealogie oraz indeksy do ksiąg podkomorskich ${ }^{57}$. W marcu 1841 r. Komisja Rządowa Sprawiedliwości, oceniając postępy przy indeksowaniu ksiąg w lubelskim archiwum oraz same indeksy, uznała za niewystarczające skorowidzowanie tylko niektórych zapisów znajdujących się w księgach i stwierdziła, że praca wykonana przez Romana nie odpowiada zamierzonym celom ${ }^{58}$. Sumariusze archiwisty nie znalazły uznania także u jednego z jego następców, Franciszka Kozłowskiego, który w 1851 r. pisał do Prezesa TC, że zostały one wykonane naprędce oraz „utrudniają kwerendy”, ponieważ nie zawierają regestu treści wpisu ${ }^{59}$.

Wraz z objęciem stanowiska archiwisty w Lublinie w 1842 r., H. Duchnowski zmienił dotychczasową koncepcję i metodę pracy przy tworzeniu sumariuszy ksiąg sądowych $^{60}$. Archiwista, wykorzystując swoje doświadczenie zawodowe, wyszedł z założenia, żeby nie indeksować wszystkich zapisów z ksiąg (np. obdukcje ran,

${ }^{53}$ Tamże, k. 2-4.

54 Tamże, k. 8.

55 APL, Asc par. pw. św. Jana w Lublinie, sygn. 21, nr 189.

${ }^{56}$ Niektóre z nich składają się dzisiaj na jednostki o sygn. 370 (dawna 24 do Ksiąg ziemskich lubelskich) [Sumariusze do ksiąg ziemskich lubelskich z serii Relacje 1700-1794] i 418 (dawna 43 do Ksiąg grodzkich krasnostawskich) [Indeksy i sumariusze do ksiąg grodzkich krasnostawskich z serii Relacje 1700-1792 i sumariusze do ksiąg grodzkich chełmskich 1700-1792].

57 Trybunał, sygn. 19, 64-64v; T. Mencel, dz. cyt., s. 27.

58 Trybunał, k. 56; T. Mencel, dz. cyt., s. 27.

59 Trybunał, sygn. 19, k. 169v.

${ }^{60}$ Duchnowski przedstawił swoją koncepcję i metody dotychczasowego działania w uwagach do „Instrukcji dla archiwów akt dawnych pod względem sporządzania skorowidzów alfabetycznych", przesłanej do archiwów jako propozycję przez Komisję Rządową Sprawiedliwości w czerwcu 1844 r. Patrz: tamże, k. 121-123v (instrukcja), k. 127-155 (propozycje Duchnowskiego). Szerzej o tym: T. Mencel, dz. cyt., s. 27-30. 
wizje dokonywane przez woźnych), a jedynie te, które były istotne z praktycznego punktu widzenia. Za zbyt praco- i czasochłonne uznał także podawanie streszczenia pełnej treści zapisu w sumariuszu, dlatego wprowadził system skrótów, które stawiane obok nazwiska lub nazwy miejscowej, wpisywanych do indeksu, miały wskazać na rodzaj dokonanej czynności prawnej odnotowanej w księdze ${ }^{61}$. Te zmiany znacząco przyspieszyły indeksowanie i - jak pisał Duchnowski - w ciągu roku archiwista z dietariuszem byli w stanie zindeksować nawet pięćdziesiąt ksiąg, zawierających zapisy z około stu lat ${ }^{62}$. O skali i tempie prac dodatkowo świadczą wnioski o zatrudnienie nowych dietariuszy i o fundusze na ich opłacenie za sporządzone indeksy, składane przez Duchnowskiego u Prezesa $\mathrm{TC}^{63}$. Tak sprzyjające warunki spowodowały, że w latach 1842-1845 ułożono 27 indeksów do ksiąg ziemskich i grodzkich różnych serii z XVI-XVIII w., powstałych w grodach: lubelskim, chełmskim oraz krasnostawskim ${ }^{64}$.

Indeksowanie ksiąg sądowych kontynuował Józef Detmerski. Nie wiemy, kiedy dokładnie powstawały sumariusze, czy ich układanie rozciągnęło się na cały czas jego pracy w archiwum lubelskim (lata 1862-1885), czy wykonano je w ciągu krótszego okresu. Dwie daty: 1872 i 1874 r., zanotowane na kartach indeksów ${ }^{65}$, mogą wskazywać, że spisywano je w latach 70. XIX w. Sygnował je swoim nazwiskiem I. Krynicki ${ }^{66}$. W wykazie akt wywiezionych z Archiwum Akt Dawnych w Lublinie do Wilna w 1887 r. odnotowano 24 indeksy wykonane przez J. Detmerskiego ${ }^{67}$. Inwentarz ten nie wymienia jednak wszystkich sumariuszy, które zachowały się do dzisiaj i które można przypisać lubelskiemu archiwiście ${ }^{68}$, dlatego podaną liczbę należy potraktować jako minimalną. Sporządził on indeksy do ksiąg ziemskich i grodzkich lubelskich głównie z XVI i XVII w., czyli do tych, które zostały

${ }^{61}$ Trybunał, sygn. 19, k. $132 \mathrm{v}$ i n.; T. Mencel, dz. cyt., s. 27-28.

${ }^{62}$ Trybunał, sygn. 19, k. 155.

63 Tamże, k. 70-74, 76-77, 82 z lat 1842-1843.

${ }^{64}$ Dane dotyczące liczby indeksów opieramy na ich treści, odzwierciedlającej metodę wprowadzoną w lubelskim archiwum przez Duchnowskiego. Por. w tej sprawie spostrzeżenia T. Mencla, dz. cyt., s. 30 .

${ }^{65}$ Zbiór indeksów, sygn. 400, ostatnia k. nlb. - 1872 r.; sygn. 367, k. 113 - 1874 r.

${ }_{66}$ Tamże. P. Dymmel w biogramie Detmerskiego wymienia jeszcze Tomasza Zakrzewskiego jako układającego indeksy, tenże, Józef Detmerski, s. 61.

${ }^{67}$ В. К. Голуб, Пятидесятилетпе виленскаго иеентральнаго архива древнииг актовыхъ книгъ, Вильна 1902, s. 107-108. T. Mencel nie podaje dokładnej liczby indeksów sporządzonych przez Detmerskiego, stwierdzając jedynie, że wykonał ich „dużo” (T. Mencel, dz. cyt., s. 31).

${ }^{68}$ Np. Zbiór indeksów, sygn. 363; sygn. 365; sygn. 365. 
pominięte przy wcześniejszym regestowaniu ${ }^{69}$. Ponadto ułożył sumariusze do księgi ziemskiej urzędowskiej i parczewskiej oraz do grodzkiej szczebrzeskiej (XVI-XVIII w.), czego nie odnotowano w wykazie z 1887 r., ale na co wskazują forma zewnętrzna oraz układ haseł w tych indeksach. Detmerski zakończył pracę w Archiwum Akt Dawnych w Lublinie w $1885 \mathrm{rr}^{70}$, ale niewykluczone, że prace nad nimi trwały jeszcze do $1887 \mathrm{r}$. i tę datę należy potraktować jako wyznaczającą koniec prac nad indeksami lubelskimi.

Tab. 1. Udział J. Romana, H. Duchnowskiego i J. Detmerskiego w tworzeniu indeksów (stan obecny)

\begin{tabular}{|c|c|c|c|}
\hline $\begin{array}{l}\text { Nazwisko archiwisty, } \\
\text { czas pracy w AAD }\end{array}$ & Indeksy do ksiąg & $\begin{array}{c}\text { Chronologia ksiąg } \\
\text { sądowych }\end{array}$ & $\begin{array}{c}\text { Sygnatura } \\
\text { indeksu }\end{array}$ \\
\hline $\begin{array}{l}\text { J. Roman } \\
\text { (1838-1841) } \\
\text { (3 indeksy) }\end{array}$ & $\begin{array}{l}\text { Różne lubelskie, chełm- } \\
\text { skie i krasnostawskie }\end{array}$ & XVIII w. & $\begin{array}{l}369 \\
370 \\
416 \\
\end{array}$ \\
\hline \multirow{5}{*}{$\begin{array}{l}\text { H. Duchnowski } \\
\text { (1842-1845) } \\
\text { (28 indeksów) } \\
\end{array}$} & $\begin{array}{l}\text { Ziemskie lubelskie } \\
\left(\operatorname{zesp}^{\star} \cdot 35 / 1\right)\end{array}$ & $\begin{array}{l}\text { 1594-1796 (zapisy) } \\
1796-1810 \text { (relacje) }\end{array}$ & $\begin{array}{l}364 \\
368\end{array}$ \\
\hline & $\begin{array}{l}\text { Ziemskie chełmskie } \\
\text { (zesp. 35/2) }\end{array}$ & 1554-1796 (zapisy) & 372 \\
\hline & $\begin{array}{l}\text { Ziemskie krasnostawskie } \\
\text { (zesp. 35/5) }\end{array}$ & $\begin{array}{l}\text { 1740-1796 (zapisy) } \\
1783-1796 \text { (relacje) }\end{array}$ & $\begin{array}{l}374 \\
375 \\
\end{array}$ \\
\hline & $\begin{array}{l}\text { Grodzkie lubelskie } \\
\text { (zesp. 35/8) }\end{array}$ & $\begin{array}{l}1700-1724 \text { (zapisy) } \\
1724-1750 \text { (zapisy) } \\
1751-1770 \text { (zapisy) } \\
1771-1787 \text { (zapisy) } \\
1531-1566 \text { (relacje) } \\
1566-1574 \text { (relacje) } \\
1575-1579 \text { (relacje) } \\
1581-1607 \text { (relacje) } \\
1608-1635 \text { (relacje) }\end{array}$ & $\begin{array}{l}385 \\
386 \\
387 \\
388 \\
393 \\
394 \\
395 \\
396 \\
397 \\
\end{array}$ \\
\hline & $\begin{array}{l}\text { Grodzkie chełmskie } \\
\text { (zesp. 35/9) }\end{array}$ & $\begin{array}{l}1402-1577 \text { (zapisy) } \\
1601-1643 \text { (zapisy) } \\
1643-1699 \text { (zapisy) } \\
1700-1792 \text { (zapisy) } \\
1600-1699 \text { (relacje) } \\
1700-1735 \text { (relacje) } \\
1736-1755 \text { (relacje) } \\
1756-1775 \text { (relacje) } \\
1776-1796 \text { (relacje) }\end{array}$ & $\begin{array}{l}402 \\
403 \\
404 \\
405 \\
406 \\
407 \\
408 \\
409 \\
410 \\
\end{array}$ \\
\hline
\end{tabular}

${ }^{69}$ В. К. Голуб, dz. cyt., s. 107-108.

${ }^{70}$ P. Dymmel, Józef Detmerski, s. 62. 


\begin{tabular}{|c|c|c|c|}
\hline $\begin{array}{l}\text { Nazwisko archiwisty, } \\
\text { czas pracy w AAD }\end{array}$ & Indeksy do ksiąg & $\begin{array}{c}\text { Chronologia ksiąg } \\
\text { sądowych }\end{array}$ & $\begin{array}{c}\text { Sygnatura } \\
\text { indeksu }\end{array}$ \\
\hline & $\begin{array}{l}\text { Grodzkie krasnostawskie } \\
\text { (zesp. 35/12) }\end{array}$ & $\begin{array}{l}1651-1712 \text { (zapisy) } \\
1713-1792 \text { (zapisy) } \\
1649-1699 \text { (relacje) } \\
1700-1743 \text { (relacje) } \\
1744-1792 \text { (relacje) }\end{array}$ & $\begin{array}{l}411 \\
412 \\
413 \\
414 \\
415 \\
\end{array}$ \\
\hline \multirow[t]{5}{*}{$\begin{array}{l}\text { J. Detmerski } \\
(1862-1885) \\
(24 \text { indeksy, } \\
\text { dzisiaj 19) }\end{array}$} & $\begin{array}{l}\text { Ziemskie lubelskie } \\
\text { (zesp. 35/1) }\end{array}$ & $\begin{array}{c}1460-1571 \text { (5/1) (zapisy) } \\
1570-1589 \text { (zapisy) } \\
1779-1796 \text { (relacje) } \\
1796-1798 \text { (relacje) } \\
1799-1810 \text { (relacje) } \\
1795-1802 \text { (ingrosacje) }\end{array}$ & $\begin{array}{l}362 \\
363 \\
365 \\
366 \\
367 \\
371\end{array}$ \\
\hline & $\begin{array}{l}\text { Grodzkie lubelskie } \\
\text { (zesp. 35/8) }\end{array}$ & $\begin{array}{l}1517-1559 \text { (zapisy) } \\
1557-1567 \text { (zapisy) } \\
1611-1620 \text { (zapisy) } \\
1621-1627 \text { (zapisy) } \\
1627-1632 \text { (zapisy) } \\
1633-1640 \text { (zapisy) } \\
1636-1688 \text { (relacje) } \\
1668-1677 \text { (relacje) } \\
1677-1679 \text { (relacje) } \\
1536-1568 \text { (wyroki) }\end{array}$ & $\begin{array}{l}379 \\
380 \\
381 \\
382 \\
383 \\
384 \\
398 \\
399 \\
400 \\
401\end{array}$ \\
\hline & $\begin{array}{l}\text { Ziemskie urzędowskie } \\
\text { (zesp. } 35 / 7 \text { ) }\end{array}$ & 1504-1581 (zapisy) & 377 \\
\hline & $\begin{array}{l}\text { Ziemskie parczewskie } \\
\text { (zesp. 35/6) }\end{array}$ & 1794-180o (relacje) & 376 \\
\hline & $\begin{array}{l}\text { Grodzkie szczebrzeskie } \\
\text { (zesp. 35/13) }\end{array}$ & $\begin{array}{c}1612-1807 \\
\text { (wszystkie serie) }\end{array}$ & 417 \\
\hline \multirow[t]{3}{*}{$\begin{array}{l}\text { Autorstwo niepewnej } \\
\text { proweniencji }\end{array}$} & $\begin{array}{l}\text { Grodzkie lubelskie } \\
\text { (z formularzem } \\
\text { drukowanym) } \\
\text { (zesp. 35/8) }\end{array}$ & $\begin{array}{l}1700-1723 \text { (zapisy) } \\
1724-1750 \text { (zapisy) } \\
1751-1770 \text { (zapisy) } \\
1771-1786 \text { (zapisy) }\end{array}$ & $\begin{array}{l}389 \\
390 \\
391 \\
392 \\
\end{array}$ \\
\hline & $\begin{array}{l}\text { Ziemskie urzędowskie } \\
\text { (zesp. 35/7) }\end{array}$ & 1585-1636 (zapisy) & 378 \\
\hline & $\begin{array}{l}\text { Podkomorskie }{ }^{71} \text { lubelskie } \\
\text { Podkomorskie lukowskie } \\
\text { Podkomorskie chełmskie }\end{array}$ & $\begin{array}{l}1434-1791 \\
\text { b.d. } \\
1443-1786\end{array}$ & $\begin{array}{l}418 \\
419 \\
420\end{array}$ \\
\hline
\end{tabular}

* Różnica wynika z połączenia kilku indeksów w jeden w Wilnie w 1896 r.

* Skrót zesp. = zespół.

${ }^{71} \mathrm{~J}$. Roman sporządził sumariusz do 9 ksiąg podkomorskich lubelskich, urzędowskich, chełmskich i krasnostawskich z lat 1416-1599 (patrz: Trybunał, sygn. 19, k. 64v). Indeksy wymienione w tabeli, ze względu na chronologię oraz częściowo proweniencję, nie wydają się być jego autorstwa. 
Zakończenie prac nad regestowaniem ksiąg sądowych grabowieckich i horodelskich zapoczątkowało nowy etap w dziejach indeksów lwowskich. Przez niespełna trzy dekady przechowywano je i korzystano z nich $\mathrm{w}$ archiwum bernardyńskim, jednak zmiany polityczne, jakie zaszły na mocy postanowień kongresu wiedeńskiego z 1815 r., spowodowały, że Grabowiec i Horodło znalazły się poza Austrią, w granicach nowo powstałego Królestwa Polskiego, połączonego unią z Cesarstwem Rosyjskim. W związku z tym Austria i Rosja porozumiały się co do przekazania ksiąg sądowych obydwu staropolskich grodów rządowi Królestwa Polskiego $z$ racji zmiany ich przynależności państwowej. Odpowiednie zapisy w tej sprawie znalazły się w konwencji dotyczącej podziału ziem Księstwa Warszawskiego między Rosję, Austrię i Prusy, podpisanej 3 V 1815 r. $^{72}$ Księgi ziemskie i grodzkie grabowieckie oraz horodelskie wraz z indeksami do nich przewieziono $\mathrm{w} 1828 \mathrm{r}$. do Warszawy, a następnie 13 IX 1829 r. do Lublina i zdeponowano je w tutejszym Archiwum Akt Dawnych ${ }^{73}$.

Konsygnacja archiwisty Piotra Zagrobskiego z 1832 r., będąca pierwszym inwentarzem akt staropolskich znajdujących się w lubelskim Archiwum Akt Dawnych, wspomina o księgach sądowych grabowieckich i horodelskich przywiezionych ze Lwowa, ale nie wymienia indeksów ${ }^{74}$. Nie odnotowano ich także przy okazji przekazania archiwum po śmierci Zagrobskiego pod zarząd jego następcy Leona Stępowskiego ${ }^{75}$. Sporządzony z tej czynności protokół (14 V 1835 r.) mówi tylko o istnieniu w zasobie archiwum ksiąg obydwu grodów, oddanych do Lublina wraz $\mathrm{z}$ trzema do nich rejestrami, spisanymi we Lwowie ${ }^{76}$. Po raz pierwszy więc po $1829 \mathrm{r}$. indeksy do ksiąg sądowych grabowieckich i horodelskich występują w „Wykazie akt dawnych w Archiwum Guberni Lubelskiej znajdujących się", powstałym w maju 1843 r. w związku z zarządzeniem wydanym przez Komisję Rządową Sprawiedliwości $^{77}$. W wykazie tym odnotowano: 13 indeksów do ksiąg ziemskich horodelskich,

${ }^{72}$ S. Sochaniewicz, dz. cyt., s. 35; Alegata do Sprawozdań Stenograficznych z Piątej Sesyi Trzeciego Peryodu Sejmu Krajowego Królestwa Galicyi i Lodomeryi wraz z Wielkim Księstwem Krakowskim z roku 1784. Alegat 1, s. 3.

${ }^{73}$ Trybunał, sygn. 41, s. 166; AGZ, s. XI; J. Riabinin, dz. cyt., s. 14; T. Mencel, dz. cyt., s. 18.

74 Trybunał, sygn. 41, s. 165-166.

${ }^{75}$ Wiadomość o przywiezieniu indeksów do ksiąg sądowych grabowieckich i horodelskich do Lublina w 1829 r. wprowadził do literatury przedmiotu w 1958 r. T. Mencel, powołując się w przypisach na akta Trybunału Cywilnego I Instancji w Lublinie oraz na książkę J. Riabinina o archiwum lubelskim (patrz: T. Mencel, dz. cyt., s. 18 i przyp. 38). W obydwu miejscach takiej informacji jednak nie znajdziemy.

76 Trybunał, sygn. 6, k. nlb.

77 Tamże, sygn. 19, s. 103. 
61 do ksiąg grodzkich horodelskich, 41 do ksiąg ziemskich grabowieckich i 245 do ksiąg grodzkich grabowieckich ${ }^{78}$. Dane z 1843 r. odpowiadają liczbie woluminów przechowywanych obecnie w Archiwum Państwowym w Lublinie. Indeksy wpisano do wykazu po rejestrze akt sądowych każdego grodu, co oznacza, że traktowano je jako części składowe poszczególnych „zespołów”. Wyróżniono je jednak jako specyficzne pomoce archiwalne, odmienne od widendarzy powstałych jeszcze w okresie funkcjonowania sądownictwa ziemskiego i grodzkiego.

Indeksy z archiwum tzw. bernardyńskiego we Lwowie w 1829 r. składały się w Archiwum Akt Dawnych w Lublinie na największą grupę regestów do ksiąg sądowych. Stopniowo, do połowy lat 8o. XIX w. uzupełniły je - biorąc pod uwagę zasięg terytorialny staropolskich sądów szlacheckich - indeksy Romana, Duchnowskiego i Detmerskiego, odnoszące się do ksiąg powstałych w kancelariach ziemskich, grodzkich i podkomorskich staropolskiego województwa lubelskiego i ziemi chełmskiej. W 1887 r., w związku z likwidacją archiwów akt dawnych w guberniach, Archiwum Akt Dawnych w Lublinie zakończyło swoją działalność ${ }^{79}$. W tym samym roku jego zasób został wywieziony do Archiwum Centralnego w Wilnie, ponieważ uznano, że odnosi się on do „ziem rosyjskich" ${ }^{\text {. }}$. Do Wilna trafiły także wszystkie wymienione indeksy ${ }^{81}$. Powróciły do Lublina w $1919 \mathrm{r}$. Wymienia je w 1926 r. Jan Riabinin ${ }^{82}$ i w 1928 r., uzupełniając w szczegółach poprzednika, Wincenty Łopaciński ${ }^{83}$.

\section{Zawartość indeksów}

Indeksy lwowskie miały służyć ułatwieniu wykonywania kwerend. Wynikało $\mathrm{z}$ tego, że w sumariuszu powinny się znaleźć regesty zapisów pochodzących z jednej księgi sądowej. Ze względu na ilość spraw rejestrowanych w księdze

${ }^{78}$ Tamże, s. $108-109$.

79 J. Riabinin, dz. cyt., s. 16-17; T. Mencel, dz. cyt., s. 35.

80 T. Mencel, dz. cyt., s. 35.

${ }^{81}$ В. К. Голуб, dz. cyt., s. 112.

82 J. Riabinin, dz. cyt., s. 21; W. Łopaciński, Kronika, „Archeion” T. IV, 1928, s. 138-141.

${ }^{83}$ W. Łopaciński, dz. cyt., s. 138-141. W wykazach staropolskich archiwaliów rewindykowanych z ZSRR w 1962 r. nie ma informacji o indeksach, a jedynie o pojedynczych księgach sądowych grabowieckich i horodelskich. Patrz: APL, Archiwum Państwowe w Lublinie, sygn. 1429, Rewindykacja archiwaliów z b. ZSRR („Wykaz ksiąg staropolskich WAP w Lublinie otrzymanych z rewindykacji z ZSRR w kwietniu 1962 r.”; „Wykaz ksiąg staropolskich WAP w Lublinie otrzymanych z rewindykacji z ZSRR w październiku 1962 r.”). 
(jej obszerność) oraz prowadzenie podwójnego systemu wpisów w protokole i indukcie zasady tej nie przestrzegano w każdym przypadku, dlatego obecnie pojedynczy indeks odnosi się do jednej księgi ${ }^{84}$, do kilku (tylko indukty; protokół i indukta) ${ }^{85}$ lub jedna księga może mieć kilka tomów indeksów, podzielonych na litery alfabetu ${ }^{86}$.

Sposób prowadzenia sumariuszy powstałych w archiwum bernardyńskim i zasada indeksowania ksiąg mają jednolity charakter. Indeks otwiera protokołowa zapiska na 1. karcie nieliczbowanej, informująca o numerze indeksu (sygnaturze) oraz numerze (sygnaturze) i rodzaju księgi (protokół, indukta), do której się odnosi. Zapiska ta jest wtórna do treści z karty tytułowej. Biorąc pod uwagę miejsce wpisu, można przypuszczać, że miała szybko informować o podstawowych danych indeksu i odsyłać do odpowiedniej księgi. Na karcie tytułowej, następnej w kolejności, znajduje się w rozwiniętej formie opis dotyczący rodzaju księgi, do której odnosi się indeks; serii, z której księga pochodzi; jej proweniencji kancelaryjnej oraz dat skrajnych. Tytuł kończy nazwisko autora indeksu ${ }^{87}$.

Zasadniczą część sumariusza stanowią regesty zapisów znajdujących się w księdze sądowej. Treść indeksu określa drukowana na każdej stronie tabela z trzema kolumnami zatytułowanymi: „Nomina”; „Species documentae”; „Pagina” - podzielona na „Protocoli” i „Inductae”. W pierwszej kolumnie, pod kolejnymi literami alfabetu znajdują się nazwiska osób działających w sprawie lub nazwy wsi bądź dóbr, których wpis dotyczy. Nie są ułożone alfabetycznie, ale w kolejności występowania w księdze od jej początku do końca, zatem o miejscu nazwiska lub nazwy miejscowej w obrębie danej litery decyduje numer strony. Druga kolumna zawiera informacje o rodzaju sprawy toczącej się pomiędzy stronami. Wyrażone są albo jednym słowem (vendit, vulneratus, donat, intromisio itp. ${ }^{88}$, albo w bardziej rozbudowanych zapiskach (np. „ratione multorum inscriptionum anteriorum et posterius efactis cum subditis violentiis") ${ }^{89}$. W ostatniej kolumnie zanotowany

\footnotetext{
${ }^{84}$ Zbiór indeksów, sygn. 1.

${ }^{85}$ Tamże, sygn. 300.

${ }^{86}$ Tamże, sygn. 245-247. Wymienione przypadki także w indeksach do ksiąg sądowych grodów staropolskiego województwa ruskiego. Patrz: P. Dąbkowski, dz. cyt., s. 88.

${ }^{87}$ P. Dąbkowski przy okazji omawiania treści indeksów do ksiąg sądowych województwa ruskiego wspomina, że na karcie tytułowej takiego indeksu podawano jeszcze datę jego powstania. Patrz: tamże. Tego elementu na kartach tytułowych naszych indeksów nie znajdziemy. Por. także: S. Sochaniewicz, dz. cyt., s. 34

${ }^{88} \mathrm{~Np}$. Zbiór indeksów, sygn. 300.

89 Tamże, sygn. 165, s. 7 - pod nazwiskiem Branicki.
} 
jest numer strony indukty i/lub protokołu, na której znajduje się wpis ${ }^{90}$. Indeksy mają więc charakter osobowo-geograficzny.

W indeksach lwowskich można ponadto sporadycznie znaleźć zapiski niezwiązane z treścią ksiąg. Są to datacje z informacją o rozpoczęciu lub zakończeniu indeksowania $^{91}$, nazwiska urzędników spisujących sumariusz ${ }^{92}$ oraz ich podpisy (manu propria) ${ }^{93}$. W indeksie do księgi grodzkiej grabowieckiej jego autor, Józef Czuryło, narysował swój herb Korczak wraz z syglami I[osephus] C[zuryło] P(incerna, pocillator?) $\mathrm{H}$ [orodlensis ${ }^{94}$, natomiast Wincenty Czuryło przedstawił na karcie indeksu do księgi grodzkiej horodelskiej swoją genealogię w formie herbu złożonego ${ }^{95}$.

Indeksy archiwistów lubelskich otwiera zazwyczaj karta tytułowa, informująca o księgach, do których zostały wykonane. Zapis taki ma formę albo opisową, podającą nazwę serii ksiąg i ich chronologię, albo szczegółową, w której wymienione są księgi pojedynczo, ich sygnatury oraz daty skrajne. Opisowy tytuł powtarzany jest często na okładce i grzbiecie woluminu (szczególnie indeksy J. Detmerskiego).

Indeksy lubelskie to indeksy osobowo-geograficzne. Zawierają nazwiska albo osób wnoszących zapis do księgi (w których imieniu wniesiono zapis) ${ }^{96}$, albo dwóch stron działających w sprawie ${ }^{97}$, a ponadto nazwy miast, wsi i dóbr (w indeksach do ksiąg podkomorskich wyłącznie), których zapis dotyczył. Indeksy spisywano dla kilku ksiąg sądowych, dlatego pod względem układu haseł możemy wyróżnić dwa ich rodzaje, nieznacznie się od siebie różniące. W pierwszej grupie (np. do ksiąg grodzkich lubelskich) w obrębie litery alfabetu zapisywano w nagłówku numer księgi i jej daty skrajne, a pod nimi nazwiska (nazwy miejscowe) ułożone według kolejności stron, na których je zapisano. W wariancie drugim (np. księgi grodzkie krasnostawskie) daną księgę rozpisywano na poszczególne lata. Hasło $\mathrm{w}$ indeksach lubelskich zawiera także określenie rodzaju sprawy (pełna nazwa lub skrót) oraz numer strony, na której znajduje się jej wpis w księdze. Indeksy do ksiąg podkomorskich są indeksami geograficznymi. W ich przypadku obok nazwy miejscowej występuje tylko numer strony.

\footnotetext{
90 Por. S. Sochaniewicz, dz. cyt., s. 34; P. Dąbkowski, dz. cyt., s. 87-88.

91 Zbiór indeksów, sygn. 21, s. 428a.

92 Tamże, sygn. 44, s. 508.

93 Tamże, sygn. 15, s. 424.

94 Tamże, sygn. 165 , k. 2v nlb.

95 Tamże, sygn. 300 (dawna 1 do 35/11 Księgi grodzkie horodelskie), k. 3v nlb.

96 Np. tamże, sygn. 411.

97 Np. tamże, sygn. 383 .
} 
W większości sumariuszy lubelskich hasła zapisane są w jednej lub w dwóch kolumnach na stronie. W czterech indeksach do ksiąg grodzkich lubelskich z XVIII w. występuje drukowana tabela, zawierająca kolumny: „Nazwisko, imię zeznającego”; „Dla kogo zeznanie nastąpiło”; „Jaka czynność”; „Numer karty” oraz bez nazwy "uwagi”, gdzie wpisywano formę zeznania (np. quietat, vendit, cedit, roborant itp. $)^{98}$. Osobną specyfikę mają sumariusze wykonane przez J. Romana (obecnie sygn. 370 i 416). Każdy zawiera dwie grupy indeksów. Pierwsza to typowe indeksy do ksiąg sądowych chełmskich, krasnostawskich i lubelskich z XVIII w. W księdze o sygn. 418 znajdują się dodatkowo indeksy do sumariuszy Romana, prawdopodobnie autorstwa H. Duchnowskiego. Druga grupa to zachowane $\mathrm{w}$ obydwu księgach zestawienia osobowo-rzeczowe mające charakter katalogów dokumentów w różnych sprawach i spisów urzędników powiatowych chełmskich, lubelskich i krasnostawskich.

\section{Charakterystyka indeksów}

Indeksy lwowskie i lubelskie mają formę księgi. Pomiędzy seriami, a także w obrębie indeksów Romana, Duchnowskiego i Detmerskiego występują jednak różnice w rozmiarach woluminów i ich oprawach. Wynikają one z czasu i odmiennych okoliczności powstania sumariuszy.

Indeksy z archiwum tzw. bernardyńskiego we Lwowie mają jednolitą formę zewnętrzną, co wskazuje, że pracownicy archiwum otrzymywali do zapisania gotową księgę. Najczęściej występujące rozmiary indeksów to: 39,5×26,0 cm i 40,0x $26,5 \mathrm{~cm}$. Inne odbiegają od nich od o, 5 do $1 \mathrm{~cm}$ w obydwu wymiarach. Woluminy, poza nielicznymi wyjątkami, oprawne są w deskę obciągniętą jasnobrązową skórą z wytłoczoną na niej bordiurą. Na skórzanym grzbiecie woluminów, pomiędzy wiązaniami, znajduje się tytuł informujący o księdze, do której indeks został sporządzony, jej sygnatury, w tym nadana we Lwowie, odrębna dla indeksów do każdego rodzaju regestowanych ksiąg (ziemskie, grodzkie) ${ }^{99}$, oraz pięciocyfrowa nadana w Wilnie. W każdym sumariuszu do krawędzi karty, na której rozpoczynają się regesty zapisów od kolejnej litery alfabetu, doklejony jest mały kartonik $\mathrm{z}$ daną literą, zapisaną po obu jego stronach. Niektóre indeksy mają dwie, nawet trzy serie alfabetu. Rozwiązanie to stosowano, gdy regestowano zapisy z więcej

\footnotetext{
98 Tamże, sygn. 388-391.

99 Por. S. Sochaniewicz, dz. cyt., s. 34.
} 
niż jednej księgi tego samego rodzaju (np. indukta) ${ }^{100}$ lub z indukty i brudnopisu obejmujących kilka lat. Wtedy jeden alfabet dotyczył zapisów z danego okresu ${ }^{101}$.

Indeksy lwowskie mają osiemnastowieczną paginację stron $\mathrm{w}$ trzech odmianach: ciągłej - wzorem współczesnej; wielokrotnej - gdy indeks ma dwa lub trzy alfabety, każda jego część ma osobną numerację stron ${ }^{102}$; wspólnej dla dwóch lub trzech indeksów do jednej księgi (drugi sumariusz kontynuuje paginację pierwszego itd. $)^{103}$.

Wszystkie indeksy z archiwum tzw. bernardyńskiego we Lwowie mają na kartach filigrany.

Indeksy Romana, Duchnowskiego i Detmerskiego formowano w tomy i oprawiano po ich spisaniu. Mają cztery rodzaje opraw. Sumariusze wykonane przez pierwszego z archiwistów oraz większość sporządzonych przez Duchnowskiego oprawne są $\mathrm{w}$ deskę obciągniętą jasnobrązową lub brązową skórą, w wielu przypadkach tłoczoną. Pozostałe mają okładki z tektury obleczonej skórą lub w formie półskórka. Ten typ oprawy charakteryzuje także indeksy do ksiąg urzędowskich, parczewskich i szczebrzeskich, ułożone przez Detmerskiego. Najbardziej jednolite pod omawianym względem są jednak sumariusze do ksiąg ziemskich i grodzkich lubelskich wykonane przez tego ostatniego. Oprawione są w tekturę obleczoną ciemnobrązowym płótnem.

W indeksach lubelskich ich twórcy stosowali foliację, ale tylko 17 sumariuszy ma ponumerowane karty. Są to głównie księgi ziemskie i grodzkie lubelskie oraz chełmskie. W przypadku sumariusza do ksiąg ziemskich lubelskich o sygn. 367 foliacja pochodzi z 1887 r., czyli z okresu późniejszego niż czas jego powstania ${ }^{104}$. Indeks do księgi grodzkiej krasnostawskiej, wykonany w archiwum bernardyńskim we Lwowie ${ }^{105}$, ma foliację prowadzoną tylko dla części księgi.

Większość indeksów Romana, Duchnowskiego i Detmerskiego ma kartoniki z kolejnymi literami alfabetu, przyklejone lub przyczepione szpilką (indeksy Detmerskiego) do krawędzi kart, na których rozpoczynają się zapisy na daną literę ${ }^{106}$.

\footnotetext{
100 Np. Zbiór indeksów, sygn. 300.

101 Np. tamże, sygn. 346.

102 Np. tamże, sygn. 300.

103 Np. tamże, sygn. 50, 51.

104 Numery kart zostały zanotowane ołówkiem o niebieskim kolorze, tak jak notatka z 1887 r. informująca o rodzaju indeksu, zapisana na karcie 1. nlb. sumariusza.

105 Zbiór indeksów, sygn. 361 (dawna 42 do 35/12 Księgi grodzkie krasnostawskie).

106 Brak ich np. w: Zbiór indeksów, sygn. 389.
} 
Niektóre sumariusze, głównie wykonane przez Duchnowskiego, mają kilka serii alfabetu odnoszących się do grup indeksowanych ksiąg sądowych.

Różnorodność indeksów lubelskich zauważalna jest także w rozmiarach woluminów. Ich wymiary wahają się od $33,5 \times 22,5^{107} \mathrm{~cm}$ do $45,5 \times 31,0 \mathrm{~cm}^{108}$.

\section{Procentowy stan zachowania indeksów}

Liczba indeksów z archiwum tzw. bernardyńskiego we Lwowie (361) nie zmieniła się od czasu ich powstania i od 1843 r., gdy po raz pierwszy odnotowano je w zasobie Archiwum Akt Dawnych w Lublinie. Podaje ją także wykaz sporządzony w $1928 \mathrm{r}$. przez Wincentego Łopacińskiego ${ }^{109}$, co oznacza, że ta część zespołu zachowała się do dzisiaj bez żadnych ubytków. Trudniej dokonać szacunków w przypadku indeksów lubelskich. Porównując ich liczbę (59) z inwentarzem ksiąg wywiezionych do Wilna w 1887 r. i uwzględniając wspomniane niedoskonałości tego spisu, możemy stwierdzić, że brak jest co najmniej 16 tomów sumariuszy. Trudność w ustaleniu właściwej liczby indeksów powstałych w Archiwum Akt Dawnych w Lublinie może polegać na błędach w ewidencji. Przykładowo, W. Łopaciński uznał dwa woluminy za indeksy do ksiąg ziemskich chełmskich z serii Ingrosacje (dawne sygn. 47, 48), gdy faktycznie były to pomoce powstałe w cesarsko-królewskiej kancelarii działającej w latach 1796-1810. Z drugiej strony, fakt odnalezienia w 2016 r. w aktach przekazanych przez Sąd Rejonowy w Lublinie do Archiwum Państwowego w Lublinie fragmentu indeksu do ksiąg grodzkich chełmskich $\mathrm{z}$ serii Zapisy z lat 1577-1600 (obecnie włączony do j.a. o sygn. 402) wskazuje, że indeksy mogły być z Archiwum Akt Dawnych wynoszone. Nie znamy także losów szeregu indeksów wykonanych przez Jana Romana, odnotowanych w dziale IV („Fragmenta Akt", poz. 14-21 i być może 22) konsygnacji spisanej po jego śmierci ${ }^{110}$. Indeksy te albo zaginęły jeszcze przed rokiem $1887^{111}$, albo nie wróciły z Wilna, jeśli przyjmiemy, że w wykazie ich nie wymieniono. Różnica w liczbie woluminów

\footnotetext{
107 Tamże, sygn. 393.

108 Tamże, sygn. 362.

109 W. Łopaciński, dz. cyt., s. 138.

110 Trybunał, sygn. 19, k. 64-64v.

111 Źródła notują konflikty Jana z Dukli Romana z adiunktem Sosnowskim na tle przepisywania przez niego notatek sporządzonych przez archiwistę („który zamiast rządowej czynności sumariusze moje i wyciągnięte notaty przepisuje dla siebie, te więc odebrałem i więcej mu nie dam"). Patrz: Trybunał, sygn. 19, k. 59.
} 
jest również wynikiem połączenia kilku indeksów w jeden. Stało się tak z trzema indeksami do ksiąg grodzkich lubelskich $\mathrm{z}$ serii Relationes $\mathrm{z}$ lat $1636-1662^{112}$ oraz $\mathrm{z}$ pięcioma do ksiąg ziemskich lubelskich z serii Zapisy z lat $1460-1571^{113}$. Prace te wykonano $\mathrm{w}$ archiwum wileńskim w $1896 \mathrm{r}$. Z kolei zestawiając cytowany już rejestr W. Łopacińskiego ( 56 woluminów) ze stanem dzisiejszym ( 59 woluminów), można odnotować, że brakuje w nim 3 indeksów, jest natomiast jeden, którego brak w obecnym zasobie.

Indeksy $\mathrm{z}$ archiwum tzw. bernardyńskiego we Lwowie oraz indeksy powstałe w Archiwum Akt Dawnych w Lublinie są dzisiaj podstawową pomocą archiwalną wykorzystywaną przy kwerendach w staropolskich księgach sądowych przechowywanych w Archiwum Państwowym w Lublinie. Wartość źródłowa indeksów polega ponadto na zachowanych $w$ nich informacjach o zapisach znajdujących się w księgach, które nie przetrwały do naszych czasów. Czynniki te oraz proweniencja kancelaryjna indeksów spowodowały, że w 2006 r. podjęto decyzję o wydzieleniu ich z zespołów ksiąg ziemskich, grodzkich i podkomorskich i utworzeniu dla nich odrębnego zespołu, co ostatecznie sfinalizowano na przełomie $2016 \mathrm{i} 2017 \mathrm{r}$. W związku z tym należy wyrazić nadzieję, że realizowany w lubelskim archiwum plan digitalizacji staropolskich ksiąg sądowych obejmie także skanowanie i udostępnienie w Internecie indeksów lwowskich i lubelskich, tworząc z nich integralną całość. Niewątpliwie dla użytkowników zasobu Archiwum Państwowego w Lublinie byłoby to znaczące ułatwienie w prowadzeniu badań.

\section{Summary}

\section{Indexes to Land, Town, and Subcamerarius Books of $18^{\text {th }}$ and $19^{\text {th }}$ Centuries in the State Archive in Lublin}

One of the most precious collections stored in the State Archive in Lublin is the $35 / 2564$ Collection of Indexes to land books, municipal books, and subcamerarius (chamberlain's) books from the holdings of the Archive of Historical Records in Lublin. These indexes were drawn up from the last quarter of the eighteenth century to the mid-nineteenth century. They were drawn up in Lvov in the so called

\footnotetext{
112 В. К. Голуб, dz. cyt., s. 107, przyp. 1. Obecnie: Zbiór indeksów, sygn. 398.

113 В. К. Голуб, dz. cyt., s. 108, przyp. 2. Por. W. Łopaciński, dz. cyt., s. 140. Obecnie: Zbiór indeksów, sygn. 362 .
} 
Bernardine Archive and the Archive of Historical Records in Lublin in order to improve queries of court records of gentry's courts from Grabowiec and Horodło (former Lublin Province and Chełm land). The indexes contain first names and surnames of people (parties) acting in the court case, kind of a case and the name of a place that the case concerns. Until 1887 the indexes were kept in Lublin. Then they were moved to Vilnius, from where they returned in 1919.

KEYwords: indexes, Bernardine archive in Lvov, Archive of Historical Records in Lublin, Jan Roman, Hieronim Duchnowski, Józef Detmerski. 